\title{
Analisis Usahatani Jamur Tiram Putih (Pleurotus ostreatus sp) Rumah Jamur Welury di Kelurahan Andai Distrik Manokwari Selatan Kabupaten Manokwari Provinsi Papua Barat
}

\author{
Yohanis Yan Makabori $^{1 *}$, Carolina Diana Mual ${ }^{1}$, Jesica Y. Enar ${ }^{1}$ \\ ${ }^{1}$ Program Studi Penyuluhan Pertanian Berkelanjutan, Politeknik Pembangunan Pertanian \\ Manokwari \\ *Corresponding author: yohanisyanmakaborimkw@gmail.com
}

\begin{abstract}
Abstrak
Penelitian ini bertujuan untuk mengetahui prospek usaha serta analisis usahatani dari budidaya jamur tiram putih. Pelaksanaan penelitian ini perlu dilakukan untuk menjawab permasalahan yang dihadapi oleh petani khususnya petani jamur tiram putih. Penelitian ini dilaksanakan selama 2 bulan terhitung mulai bulan maret sampai mei 2021. Metode analisis data yang digunakan adalah observasi partisipatif. Biaya yang di keluarkan untuk satu kali proses produksi budidaya jamur tiram dengan skala luas kumbung 7,9 m x 2,8 m adalah sebesar Rp.13.486.325. Biaya tersebut antara lain biaya tetap dan biaya variabel. Harga jual jamur tiram Rp.100.000/ $\mathrm{kg}$ dan total pendapatan Rp.24.713.675. Produksi jamur tiram selama 8 bulan sebanyak $382 \mathrm{~kg}$ dengan total penerimaan Rp.38.200.000. Hasil analisis B/C ratio menunjukan angka 1.82 artinya usaha jamur tiram yang dijalankan menguntungkan. Berdasarkan BEP Produksi pada penjual 134,86 kg jamur tiram terjadi Break Even Point dan pada pejualan ke $135 \mathrm{~kg}$ jamur tiram, baru mulai memperoleh keuntungan. BEP Harga 35.304 Artinya dengan produksi $382 \mathrm{Kg}$ jamur, maka titik impas modal terjadi jika harga jamur Rp. 35.304. BEP Penerimaan 13.162.828 Artinya usaha jamur tiram putih yang dijalankan oleh petani Rumah Jamur Welury satu kali produksi mampu memberikan keuntungan karena total penerimaan lebih tinggi dari nilai titik impas yang diperoleh dari perhitungan BEP Penerimaan.
\end{abstract}

Kata Kunci: Analisis BEP, Analisis Pendapatan, Analisis Penerimaan, B/C Ratio

\section{Abstract}

This study aims to determine the business prospects and analysis of farming of white oyster mushroom cultivation. The implementation of this research needs to be done to answer the problems faced by farmers, especially white oyster mushroom farmers. This research was carried out for 2 months starting from March to May 2021. The data analysis method used was participatory observation. The costs incurred for a one-time production process of oyster mushroom cultivation with an area of $7.9 m \times 2.8 m$ kumbung is Rp. 13.486.325. These costs include fixed costs and variable costs. The selling price of oyster mushrooms is $R p .100,000 / \mathrm{kg}$ and the total income is $R p$. 24.713.675. Oyster mushroom production for 8 months was $382 \mathrm{~kg}$ with a total revenue of Rp. $38.200,000$. The results of the analysis of the B/C ratio show the number 1.82 , which means that the oyster mushroom business that is run is profitable. Based on the BEP Production of the seller of $134,86 \mathrm{~kg}$ of oyster mushrooms, a Break Even Point occurred and on the sale of $135 \mathrm{~kg}$ of oyster mushrooms, he just started to make a profit. BEP Price 35.304 This means that with the production of $382 \mathrm{Kg}$ of mushrooms, the break-even point occurs if the price of mushrooms is Rp. 35.304. BEP Revenue 13.162.828 This means that the white oyster mushroom business run by the farmer of the Welury Mushroom House is able to provide a profit because the total revenue is higher than the break-even point value obtained from the calculation of the BEP Revenue.

Keywords: BEP analysis, B/C ratio, Income analysis, Revenue analysis 
Prosiding Seminar Nasional Pembangunan dan Pendidikan Vokasi Pertanian

Politeknik Pembangunan Pertanian Manokwari, 31 Juli 2021

e ISSN : 2774-1982

DOI : https://doi.org/10.47687/snppvp.v2i1.194

\section{PENDAHULUAN}

Jamur konsumsi atau sering dikenal dengan istilah mushroom merupakan bahan makanan sumber protein yang cukup digemari masyarakat. Berdasarkan urutannya yang paling banyak dibudidayakan, yakni jamur kancing (Agricus bisporus), jamur shitek (Lentinus edodes) jamur enokitake (Flammulina velutipes), jamur merang (Volvariella volvaceae), dan jamur tiram (Pleurotus ostreatus sp) (Sumarsih, 2010). Jamur tiram merupakan jenis jamur yang cukup popular yang banyak dibudidayakan dan dikonsumsi oleh masyarakat Indonesia.

Menurut sejarah jamur tiram sudah dibudidayakan di Cina sejak 1000 tahun yang lalu, sementara itu di Indonesia mulai dibudidayakan pada tahun 1980 di Wonosobo (Rahmat et al., 2011). Permintaan jamur tiram yang cukup tinggi masih belum terpenuhi, masih banyak yang di datangkan dari luar daerah. Berdasarkan hal tersebut perlu dilakukan budidaya jamur tiram (Zulfarina et al., 2019).

Komoditas tanaman hortikultura di Indonesia memiliki beragam jenis dan dapat dibagi menjadi empat kelompok besar, yaitu tanaman buah-buahan, tanaman sayuran, tanaman biofarmaka dan tanaman hias. Tanaman hortikultura yang memiliki peranan penting bagi kehidupan sehari-hari manusia adalah sayur-sayuran karena merupakan sumber gizi bagi tubuh manusia. Selain itu jamur tiram merupakan jenis komoditi yang memiliki nilai ekonomi tinggi. Hal tersebut karena jamur tiram dapat dijadikan sebagai sumber pedapatan bagi petani (Soares, 2013). Tingginya nilai ekonomi pada jamur tiram ini dapat menjadi peluang usaha. Menurut Makabori dan Tapi (2019), minat usaha dapat terbentuk dari adanya peluang usaha yang memiliki nilai ekonomi tinggi.

Besarnya permintaan jamur tiram dipasaran membuat petani jamur memiliki harapan besar untuk memperoleh pendapatan yang besar dari hasil budidaya jamur tiram. di Provinsi Papua Barat produksi jamur tahun 2019 sebanyak $355.00 \mathrm{~kg} / \mathrm{thn}$ (Badan Pusat Statistik, 2019). Berdasarkan data ini dapat disimpulkan bahwa produksi jamur di Papua Barat sangat minim sehingga perlu di kaji peluang agribisnis jamur tiram secara valid.

Berdasarkan latar belakang tersebut dapat dikemukakan rumusan masalah bahwa sekilas usaha jamur memiliki prospek yang menguntungkan, tetapi belum jelas apakah bisnis ini memang memiliki prospek yang menguntungkan? Masalahnya penanganan atau pengelolaan usaha jamur belum ditangani dengan baik dan benar. Oleh sebab itu perlu dilakukan analisis usaha untuk mengetahui gambaran prospek usaha jamur tersebut. 
Prosiding Seminar Nasional Pembangunan dan Pendidikan Vokasi Pertanian

Politeknik Pembangunan Pertanian Manokwari, 31 Juli 2021

e ISSN : 2774-1982

DOI : https://doi.org/10.47687/snppvp.v2i1.194

Adapun tujuan yang ingin dicapai, yaitu mengetahui prospek usaha jamur tiram di Manokwari dan mengetahui analisis Usahatani untuk gambaran prospek usaha jamur tiram.

\section{METODE}

Penelitian dilaksanakan selama dua bulan terhitung dari bulan Maret sampai Mei 2021, yang berlokasi di Kelurahan Andai Distrik Manokwari Selatan Kabupaten Manokwari. Metode pemilihan lokasi pada penelitian ini dilakukan secara purposive (sengaja) yaitu di Rumah Jamur Welury. Pengumpulan data dilakukan dengan metode observasi partisipatif yaitu dengan ikut serta dalam kegiatan pekerjaan dan pengamatan tentang pokok-pokok pembahasan.

Data yang digunakan dalam penelitian ini adalah data primer dan data sekunder. Data primer diperoleh dengan cara mengandalkan pengamatan langsung dilokasi penelitian dan wawancara dengan informan, dengan menggunakan daftar pertanyaan yang telah disusun sesuai dengan tujuan penelitian. Data sekunder diperoleh dari literatur, dinas pertanian kabupaten, BPS dan monografi desa/kecamatan.

Metode analisis data yang digunakan adalah metode kualitatif (deskriptif) merupakan sumber data yang ditampilkan dalam bentuk abstrak atau merupakan suatu data yang bukan merupakan data angka sehingga tidak dapat diperhitungkan dan di ukur. Metode kuantitatif digunakan untuk menganalisis biaya produksi, penerimaan dan pendapatan jamur tiram.

1) Total Biaya Produksi, Penerimaan, dan Pendapatan dapat dihitung menggunakan rumus Sadono (2006):

a) Rumus Biaya Produksi :

$\mathrm{TC}=\mathrm{TFC}+\mathrm{TVC}$

Keterangan :

$\mathrm{TC}=$ Total Cost (Biaya Total)

TFC $=$ Total Fixed Cost (Total Biaya Tetap)

$\mathrm{TVC}=$ Total Variable Cost $\quad($ Total Biaya Variabel $)$

b) Rumus Penerimaan :

$\mathbf{T R}=\mathbf{P} \cdot \mathbf{Q}$

Keterangan :

$\mathrm{TR}=$ Total Revenue $($ Total Penerimaan $) \mathrm{P}=$ Price $($ Harga $)$

$\mathrm{Q}=$ Quantity (Jumlah Produksi) 
Prosiding Seminar Nasional Pembangunan dan Pendidikan Vokasi Pertanian

Politeknik Pembangunan Pertanian Manokwari, 31 Juli 2021

e ISSN : 2774-1982

DOI : https://doi.org/10.47687/snppvp.v2i1.194

c) Rumus Pendapatan :

$\pi=$ TR-TC

Keterangan :

$\pi=$ keuntungan bersih $(\mathrm{Rp})$

$\mathrm{TR}=$ Total Penerimaan $(\mathrm{Rp})$

$\mathrm{TC}=$ Biaya Total $(\mathrm{Rp})$

2) Analisis Kelayakan Usaha

a) Analisis Rasio Keuntungan atas Biaya dihitung dengan menggunakan rumus (Hasanah, 2018) :

$$
\mathrm{B} / \mathrm{C}=\frac{\pi}{\mathrm{TC}}
$$

Usaha jamur tiram putih dikatakan layak apabila nilai $\mathrm{B} / \mathrm{C}>0$

b) Analisis Break Event Point (BEP)

Analisis titik impas atau BEP merupakan cara untuk mengetahui batas penjualan minimum agar suatu perusahaan tidak menderita kerugian tetapi belum memperoleh laba atau laba sama dengan nol. Secara matematik, analisis BEP dapat dihitung dengan rumus (Gray C. dkk, 1993) dalam Wattimena (2020), sebagai berikut:

$$
\begin{gathered}
\text { BEP Produksi }=\frac{\text { biaya total }}{\text { harga jual }} \\
\text { BEP Harga jual }=\frac{\text { biaya total }}{\text { volume produksi }} \\
\text { BEP Penerimaan }=\frac{\text { total biaya tetap }}{1-(\text { total biaya variabel }: \text { penerimaan total })}
\end{gathered}
$$

\section{HASIL DAN PEMBAHASAN}

Dari hasil pengamatan dapat dilihat pada Tabel 1 dan Gambar 1, yaitu produksi jamur tiram dari bulan Oktober terus meningkat dan mencapai produksi maksimal pada bulan Desember sampai bulan Februari dan mulai mengalami penurunan produksi pada bulan Maret sampai Mei. Faktor yang yang menjadi penyebab turunnya jumlah produksi jamur tiram putih adalah dengan berlakunya Hukum Pertambahan Hasil yang Semakin Menurun (The Law of Deminishing Returns) yang dikemukakan oleh Bruce (1994) dalam Watimena (2020), yang menyatakan bahwa kenaikan hasil akan mengalami titik optimum produksi yang paling tinggi setelah itu akan mengalami penurunan hasil produksi. Kasus ini membuktikan bahwa hukum The Law of Deminishing Returns terbukti. 
Prosiding Seminar Nasional Pembangunan dan Pendidikan Vokasi Pertanian

Politeknik Pembangunan Pertanian Manokwari, 31 Juli 2021

e ISSN : 2774-1982

DOI : https://doi.org/10.47687/snppvp.v2i1.194

Tabel 1. Tabel Produksi Jamur Tiram

\begin{tabular}{clc}
\hline No & \multicolumn{1}{c}{ Bulan } & Jumlah produksi $(\mathrm{Kg})$ \\
\hline 1 & Oktober & 32 \\
2 & November & 44 \\
3 & Desember & 60 \\
4 & Januari & 62 \\
5 & Februari & 61 \\
6 & Maret & 55 \\
7 & April & 47 \\
8 & Mei & 21 \\
\hline \multicolumn{2}{r}{ Jumlah } \\
\hline
\end{tabular}

Produksi maksimal jamur tiram adalah 6 bulan, tetapi karena usaha jamur ini adalah usaha sampingan petani tidak terlalu memperhatikan masa produksinya sehingga baglog yang seharusnya pada bulan Maret sudah diganti dengan yang baru disana masih dipertahankan (Toni, 2019). Baglog dapat di panen 5 sampai 8 kali selama masa produksi apabila dirawat dengan baik dan baglog yang beratnya $1 \mathrm{~kg}$ menghasilkan $0,5-0,8 \mathrm{~kg} \mathrm{~kg}$ jamur tiram. Apabila permukaan baglog tertutup sempurna dengan miselium, kira-kira 2-3 minggu setelah pembukaan baglog jamur sudah mulai tumbuh dan sudah dapat dipanen.

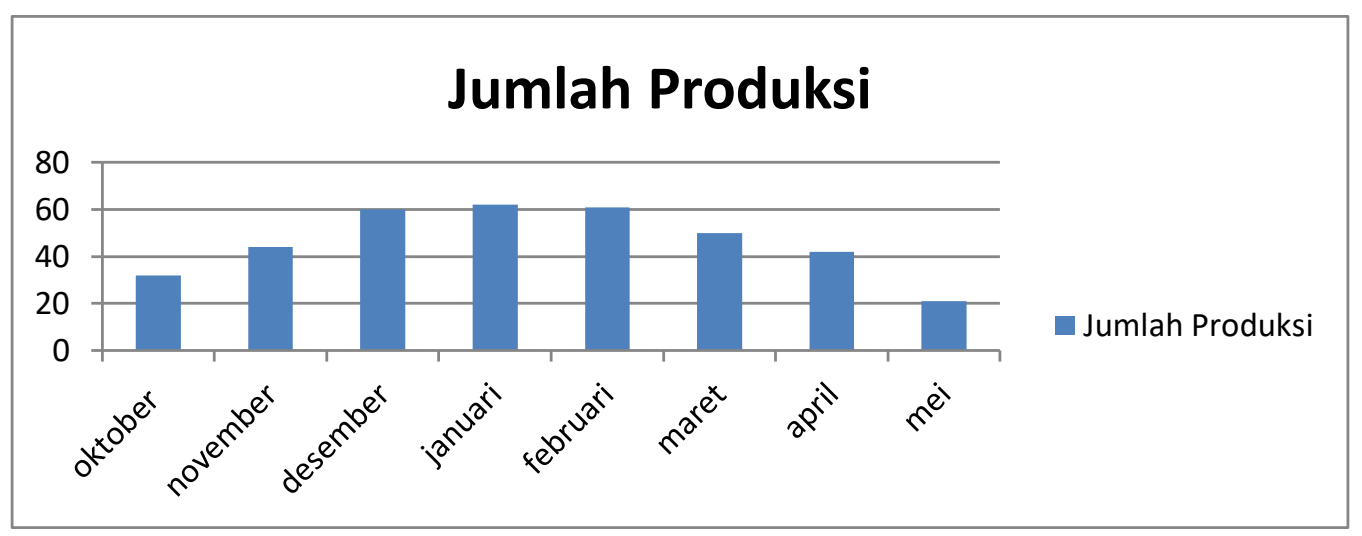

Gambar 1. Grafik produksi Jamur Tiram

\section{Biaya produksi jamur tiram putih untuk satu kali produksi}

Biaya untuk satu kali proses produksi budidaya jamur tiram dengan skala luas kumbung 7,9m x 2,8m adalah sebesar Rp.13.486.325 biaya produksi terdiri dari biaya tetap dan biaya tidak tetap. Biaya tetap terdiri dari biaya penyusutan kumbung, biaya penyusutan alat, tenaga kerja, dan biaya lain-lain. 
Prosiding Seminar Nasional Pembangunan dan Pendidikan Vokasi Pertanian

Politeknik Pembangunan Pertanian Manokwari, 31 Juli 2021

e ISSN : 2774-1982

DOI : https://doi.org/10.47687/snppvp.v2i1.194

Tabel 2. Biaya tetap produksi jamur tiram

\begin{tabular}{clr}
\hline No & \multicolumn{1}{c}{ Uraian } & Jumlah (Rp) \\
\hline 1. & Penyusutan Kumbung & 128.000 \\
2. & Penyusutan alat & 63.200 \\
3. & Tenaga kerja & 10.000 .000 \\
4. & Biaya lain-lain: & \\
& a. Listrik & 120.000 \\
& b. sewa lahan & 2.400 .000 \\
& c. Transportasi & 120.000 \\
& d. biaya tak terduga & 200.000 \\
\hline \multicolumn{2}{c}{ Total } \\
\hline
\end{tabular}

Biaya penyusutan kumbung di hitung dalam 1 kali produksi. Kumbung yang dibuat sebanyak 1 buah dengan luas 7,9 m x 2,8 m. Biaya penyusutan alat yang dimaksudkan adalah biaya penyusutan terhadap alat-alat yang digunakan untuk produksi jamur tiram putih. Biaya tenaga kerja yang di perhitungkan adalah jenis kegiatan budidaya adalah pemeliharaan baglog. Tugas pemeliharaan rutin 1 orang setiap hari dan pada tahapantahapan tertentu misalnya pengisian baglog, perbaikan/pemeliharaan kumbung dan lain sebagainya menggunakan tenaga tambahan kurang lebih 20 HOK dengan upah Rp.50.000 sesuai beban kerja. Biaya lain-lain yang dimaksudkan adalah biaya-biaya yang dikeluarkan untuk menunjang kegiatan budidaya jamur tiram putih selama proses produksi yang meliputi biaya listrik, sewa lahan, transportasi dan biaya tak terduga yang disediakan untuk pengeluaran yang diluar perencanaan (tidak diperkirakan).

Table 3. Biaya tidak tetap produksi jamur tiram

\begin{tabular}{|c|c|c|c|c|}
\hline No & Uraian & Volume & Harga satuan (Rp) & Jumlah (Rp) \\
\hline 1 & Serbuk Gergaji & $100 \mathrm{~kg}$ & 200 & 20.000 \\
\hline 2 & Bibit F1 & 3 botol & 50.000 & 150.000 \\
\hline 3 & Tepung Jagung & $5 \mathrm{~kg}$ & 11.000 & 55.000 \\
\hline 4 & Plastik Polipropilena (PP) & $1 \mathrm{~kg}$ & 30.000 & 30.000 \\
\hline 5 & Karet Gelang & $1 \mathrm{~kg}$ & 50.000 & 50.000 \\
\hline 6 & Kertas/Koran & $1 \mathrm{~kg}$ & 5.000 & 5.000 \\
\hline 7 & Alcohol & 1 botol & 60.000 & 60.000 \\
\hline 8 & Spritus & 1 botol & 25.000 & 25.000 \\
\hline 9 & Kapur & $1,5 \mathrm{~kg}$ & 2.000 & 3.000 \\
\hline 10 & Gypsum & $1,5 \mathrm{~kg}$ & 4.750 & 7.125 \\
\hline 11 & Tali Plastik & 5 meter & 1.000 & 5.000 \\
\hline 12 & Dedak & $15 \mathrm{~kg}$ & 3.000 & 45.000 \\
\hline
\end{tabular}


Prosiding Seminar Nasional Pembangunan dan Pendidikan Vokasi Pertanian

Politeknik Pembangunan Pertanian Manokwari, 31 Juli 2021

e ISSN : 2774-1982

DOI : https://doi.org/10.47687/snppvp.v2i1.194

Biaya tidak tetap terdiri dari biaya bahan-bahan yang digunakan dalam produksi baglog jamur tiram putih. Total biaya 1 kali produksi jamur tiram adalah Rp.13.486.325.

\section{Penerimaan}

Penerimaan usahatani adalah perkalian antara produksi yang diperoleh dengan harga jual. Penerimaan juga sangat ditentukan oleh besar kecilnya produksi yang dihasilkan dan harga dari produksi tersebut (Zaman et al., 2021). Total penerimaan dari usaha budidaya jamur tiram per musim panen sebesar Rp. 38.200.000, dengan jumlah produksi sebesar $382 \mathrm{Kg}$ dan harga jual jamur tiram sebesar Rp. 100.000/kg.

\section{Pendapatan}

Pendapatan diperoleh dengan mengurangkan total penerimaan dengan total biaya yang dikeluarkan. Usaha dikatakan untung apabila penerimaan lebih tinggi dari pada total biaya dan sebaliknya apabila total biaya lebih besar dari pada penerimaan, maka dikatakan rugi (Watimena, 2020). Penerimaan usaha budidaya jamur tiram sebesar Rp. 38.200.000 dan total biaya produksi sebesar Rp 13.486.325. Maka pendapatan usaha budidaya jamur tiram yaitu Rp. 24.713.675 per musim panen.

\section{Analisis kelayakan usaha}

Suatu usaha dapat dikatakan layak diusahakan apabila pengusaha memperoleh keuntungan dari usaha yang dilakukannya. Manajemen yang baik dari suatu usaha itu akan dapat memberikan keuntungan yang maksimal. Untuk mengetahui apakah usaha budidaya jamur tiram yang dilakukan petani di Kampung Weluri Kelurahan Andai sudah layak atau tidak dijalankan, maka dapat dianalisis dengan menggunakan analisis Benefit Cost Ratio (B/C) Ratio yaitu:

$$
\begin{aligned}
B / C & =\frac{24.713 \cdot 675}{13.486 .325} \\
& =1,82
\end{aligned}
$$

Dari hasil perhitungan diatas didapat nilai $\mathrm{B} / \mathrm{C}$ ratio sebesar 1,82. Nilai 1,82 >0, sehingga dapat disimpulkan bahwa usaha budidaya jamur tiram layak dijalankan.

\section{Prospek Usaha}

Adapun beberapa hal yang perlu dipertimbangkan untuk melihat prospek yang akan datang sehingga menjadikan usaha ini layak untuk diusahakan antara lain:

a. Berdasarkan BEP produksi dapat dihitung:

$$
\begin{aligned}
\text { BEP Produksi } & =\frac{13.486 .325}{100.000} \\
& =134,86
\end{aligned}
$$


Prosiding Seminar Nasional Pembangunan dan Pendidikan Vokasi Pertanian

Politeknik Pembangunan Pertanian Manokwari, 31 Juli 2021

e ISSN : 2774-1982

DOI : https://doi.org/10.47687/snppvp.v2i1.194

Artinya perlu menjual 134,86 kg jamur tiram agar terjadi Break Even Point. Pada penjualan ke $135 \mathrm{~kg}$ jamur tiram, baru mulai memperoleh keuntungan. BEP Produksi 134,84 dapat diperoleh pada minggu ke-4 di bulan Desember.

b. Berdasarkan BEP Harga dapat dihitung:

$$
\begin{aligned}
\text { BEP Harga } & =\frac{13.486 .325}{382 \mathrm{~kg}} \\
& =35.304
\end{aligned}
$$

Artinya dengan produksi $382 \mathrm{~kg}$ jamur, maka titik impas modal terjadi jika harga jamur Rp. 35.304

c. Berdasarkan BEP Penerimaan dapat dihitung:

$$
\begin{aligned}
B E P \text { Penerimaan } & =\frac{13.031 .200}{1-(455.125: 38.200 .000)} \\
& =13.162 .828
\end{aligned}
$$

Artinya usaha jamur tiram putih yang dijalankan oleh petani Rumah Jamur Welury satu kali produksi mampu memberikan keuntungan karena total penerimaan lebih tinggi dari nilai titik impas yang diperoleh dari perhitungan BEP Penerimaan.

d. Peningkatan pemasarannya, yaitu dengan meningkatkan promosi untuk membuka pasar yang lebih luas. Petani jamur tiram Rumah Jamur Welury hanya memasarkan hasil lewat media Whatsapp saja, hal ini juga harus didukung dengan data administrasi yang lebih tertib.

e. Efisiensi dan efektifitas pemeliharaan.

Kelembaban ruangan dalam kumbung jamur tiram harus dijaga untuk mengoptimalkan produktifitas di bulan-bulan yang produksinya menurun dengan cara lantai dibiarkan basah atau becek (Lantai rumah Jamur Welury terbuat dari tanah liat), dilakukan penyiraman rutin 2 kali sehari (pagi dan sore), dilakukan pemupukan untuk menjaga kesuburan baglog dan perlu digunakan pestisida untuk mengendalikan hama yang dapat menurunkan masa pakai baglog dan menurunkan produksi jamur tiram. Produksi jamur tiram diharapkan dapat dipertahankan lebih lama lagi.

f. Banyak penduduk yang belum bekerja. Artinya tempat usaha Rumah Jamur Kampung Welury bisa menjadi lapangan pekerjaan bagi penduduk yang belum bekerja.

\section{KESIMPULAN DAN SARAN}

Berdasarkan hasil penelitian yang telah dilakukan, maka dapat diambil beberapa kesimpulan sebagai berikut. Usaha jamur tiram putih ini layak untuk dijalankan karena 
Prosiding Seminar Nasional Pembangunan dan Pendidikan Vokasi Pertanian

Politeknik Pembangunan Pertanian Manokwari, 31 Juli 2021

e ISSN : 2774-1982

DOI : https://doi.org/10.47687/snppvp.v2i1.194

mendatangkan keuntungan. Hal ini ditunjang oleh beberapa hasil analisis yaitu BEP Produksi 134,86 kg dari $382 \mathrm{~kg}$ total produksi jamur tiram, BEP Harga Rp.35.304 per kg dari Rp.100.000 per kg dan BEP Penerimaan Rp.13.162.828 dari total penerimaan Rp.38.200.000 serta Analisis B/C Ratio $1.82>$ 0, artinya usaha layak dijalankan. Penerimaan usaha budidaya jamur tiram selama 8 bulan sebesar Rp. 38.200.000 dan total biaya yang dikeluarkan petani sebesar Rp. 13.486.325. Dengan demikian pendapatan usaha budidaya jamur tiram sebesar Rp. 24.713.675. Perlunya meningkatkan pengelolaan baik secara teknis maupun manajemen yang lebih intensif agar dapat diperoleh hasil yang lebih optimal.

\section{DAFTAR PUSTAKA}

Badan Pusat Statistik. (2019) Produksi Tanaman Sayuran Tahun 2019.

Hasanah, L. (2018). Analisis Biaya Produksi dan Pendapatan F3 (Filial 3) Jamur Tiram Putih Di Cv Rst.

Makabori, Y.Y. \& Tapi, T. (2019). Generasi Muda Dan Pekerjaan Di Sektor Pertanian : Faktor Persepsi dan Minat (Studi Kasus Mahasiswa Politeknik Pembangunan Pertanian Manokwari). Jurnal Triton, 10(2), 1-20.

Rahmat, S. \& Nurhidayat. (2011). Untung Besar Dari Bisnis Jamur Tiram. Agromedia Pustaka. Jakarta

Sadono. (2006). Ekonomi Pembangunan: Proses, Masalah, dan Dasa Kebijakan. Jakarta: Prenada Media Group.

Soares, A.P. (2013). Langkah Pencegahan Virus Corona, Journal of Chemical Information and Modeling, 53(9), 1689-1699.

Sumarsih, S. (2010). Untung Besar Usaha Bibit Jamur Tiram. Jakarta: Penebar Swadaya.

Toni. (2019). Budidaya Jamur Tiram. PPL BPP Kecamatan Kajen Kab. Pekalongan. Published on cyber extension - Pusluhtan Kementan.

Watimena, L. (2020). Analisis Biaya Produksi dan Pendapatan Usaha Jamur Tiram Putih Pada Usaha D'PAPUA JAMUR Di kelurahan Malasom Kabupaten Sorong

Zaman, N., Nurlina, N., Simarmata, M. M. T., Permatasari, P., Utomo, B., Amruddin, A., Anwarudin, O., Firdaus, E., Rusdiyana, E., \& Zulfiyana, V. (2021). Manajemen Usahatani, Medan: Yayasan Kita Menulis.

Zulfahrina, Z., Suryawati, E., Yustina, Y., Putra, R. A. \& Taufik, H. (2019). Budidaya Jamur Tiram dan Olahannya Untuk Kemandirian Masyarakat Desa. Jurnal Pengabdian Kepada Masyarakat (Indonesian Jurnal Of Community Engagement), 5(3), 358. 